\title{
An inquiline deep-water bryozoan/amphipod association from New Zealand, including the description of a new genus and species of Chevaliidae
}

\author{
Anne-Nina LÖRZ 1,5,*, Alan MYERS ${ }^{2,3,6}$ \& Dennis GORDON 1,4,7 \\ ${ }^{1}$ National Institute of Water \& Atmospheric Research, Private Bag 14-901, \\ Kilbirnie Wellington, New Zealand \\ ${ }^{2}$ School of Biological, Earth and Environmental Sciences, University College, Cork, \\ Cork Enterprise Centre, Distillery Fields, North Mall, Cork, Ireland \\ ${ }^{*}$ Corresponding author. E-mail: Anne-Nina.Loerz@niwa.co.nz \\ ${ }^{3}$ E-mail: bavayia@gmail.com \\ ${ }^{4}$ E-mail: Dennis.Gordon@niwa.co.nz \\ ${ }^{5}$ urn:1sid:zoobank.org:author:9442484E-43A4-4383-A1A6-AE493087BCA1 \\ ${ }^{6}$ urn:lsid:zoobank.org:author:68E417C5-1A1D-4FBC-B832-2A0EBEE79DF1 \\ ${ }^{7}$ urn:1sid:zoobank.org:author:DD9C0F3A-8512-4AC8-B395-7687CE3FC565
}

\begin{abstract}
For the first time Amphipoda have been discovered living in Bryozoa. A new genus and species of the amphipod family Chevaliidae, Bryoconversor tutus gen. et sp. nov. is described from New Zealand at depths of 530-1500 m. The species lives in an inquiline relationship with the cheilostome bryozoan Onchoporoides moseleyi (Calwelliidae), inhabiting an abfrontal basal coelom of the bryozoan beneath the membranous ectocyst (cuticularized epithelium) that conceals and protects the amphipods. The colony is strengthened along all edges by a unique intracoelomic rod of calcium carbonate that is formed within the marginal kenozooids of the colony. The potential benefits and costs to the bryozoan are discussed.
\end{abstract}

Key words. Amphipoda, Chevaliidae, Bryozoa, commensalism, New Zealand.

Lörz A-N., Myers A. \& Gordon D. 2014. An inquiline deep-water bryozoan/amphipod association from New Zealand, including the description of a new genus and species of Chevaliidae. European Journal of Taxonomy 72 : 1-17. http://dx.doi.org/10.5852/ejt.2014.72

\section{Introduction}

Amphipoda are known to be associated with many different invertebrates, including decapod crustaceans (Myers 1974; Vader \& Myers 1996; Vader \& Krapp 2005), molluscs (Vader 1972), actiniarians (Vader 1984), ascidians (White \& Reimer 2012a) and sponges (Lörz \& De Broyer 2004; White \& Reimer 2012b). Bryozoans are also known to be associated symbiotically with a variety of invertebrates, including sponges (Harmelin et al. 1994), corals (McKinney et al. 1990), athecate hydroids (Puce et al. 2007), polychaetes (Ehlers 1876), hermit crabs (Taylor 1994) and other decapod crustaceans (e.g., Eggleston 
1971; Gordon \& Wear 1999). D'Hondt (1983), Hayward (1985) and Cook (1985) documented a range of additional associations between bryozoans and other organisms, from mutualistic to parasitic.

Until now, the Chevaliidae was considered a monotypic family and the single genus Chevalia Walker, 1904 has been reported from amongst algae, coral rubble, 'various invertebrates' and dead coral. However, the type species (C. aviculae Walker, 1904) was found in washings from pearl oysters and at least one species (C. setosa Sousa Filho, Souza \& Valerio-Bérardo, 2010) is known to be associated with sponges, although the exact nature of the relationship is unknown.

Here we report the first known association between an amphipod and a bryozoan. A new genus and species of chevaliid amphipod was discovered beneath the membranous ectocyst (cuticularized epithelium) covering a colony-wide abfrontal basal coelom in the bryozoan Onchoporoides moseleyi (Busk, 1884), in New Zealand deep waters. It is described and illustrated here as Bryoconversor tutus gen. et sp. nov. The bryozoan is an erect, planar form with flattened fronds that bifurcate at intervals. It is relatively weakly calcified but its unique mode of strengthening its margins is described herein. The nature of the relationship and whether one or both parties benefit is discussed.

\section{Material and Methods}

Recent and historic collections of the bryozoan Onchoporoides moseleyi from New Zealand waters held at the Marine Invertebrate Collection, National Institute of Water \& Atmospheric research (NIWA),

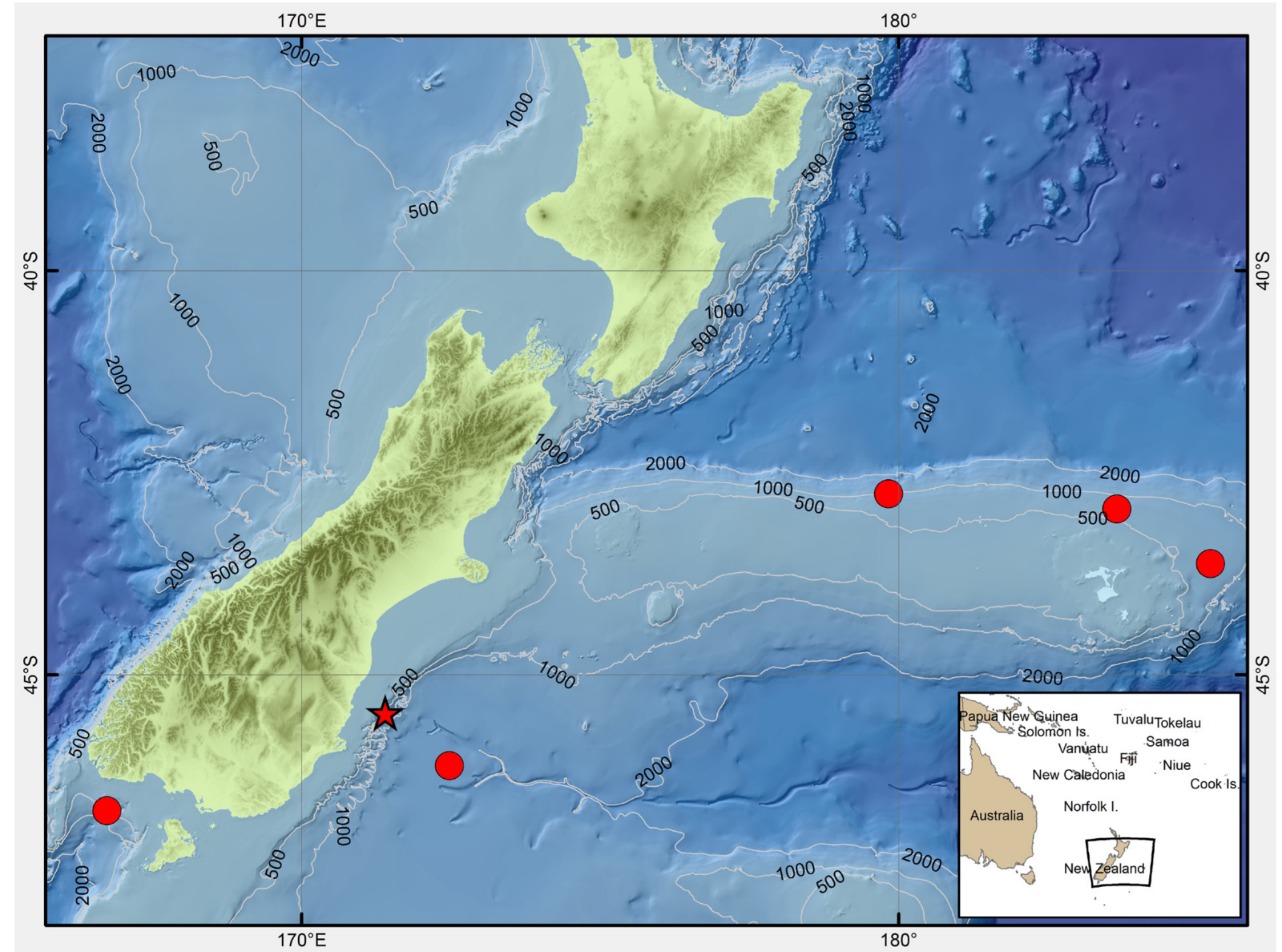

Fig. 1. Sampling localities of the calwelliid bryozoan Onchoporoides moseleyi harboring Bryoconversor tutus gen. et sp. nov. The type locality is indicated by a star. 
were investigated. Almost 100 colonies were examined, $95 \%$ of them hosting amphipods, from six localities. The distribution map (Fig. 1) was created in ArcGIS.

Amphipoda were removed after being photographed in their host (Fig. 2A) and transferred to 70\% ethanol. Specimens were examined and dissected under a Leica MZ9.5 stereoscope and an Axioscope 2 Plus Zeiss microscope, and dissected parts were mounted in glycerin and drawn using a camera lucida.

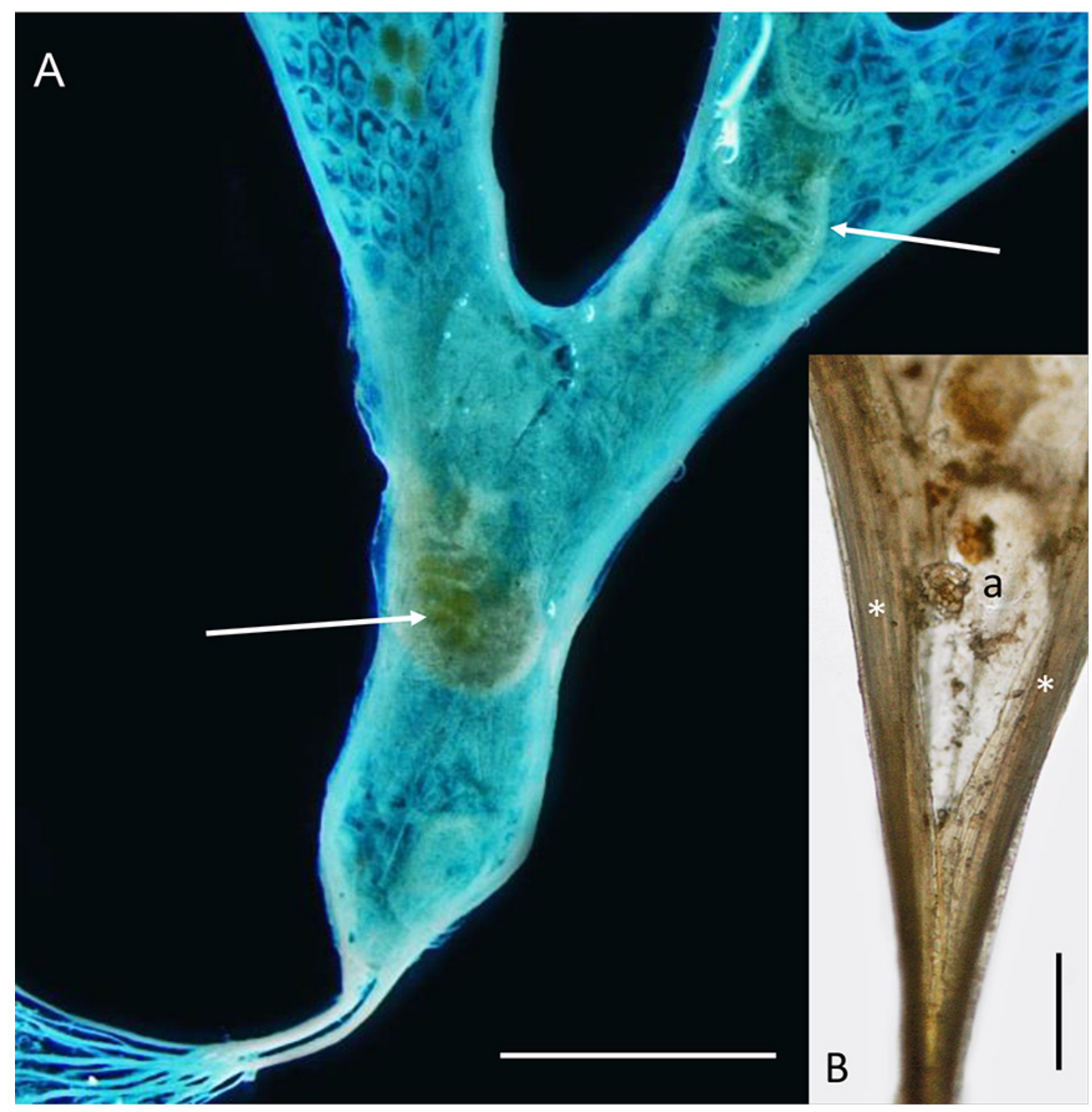

Fig. 2. A. Photograph of the abfrontal side of a colony of the bryozoan Onchoporoides moseleyi showing adults (middle left arrow) and juveniles (upper right arrow) of Bryoconversor tutus gen. et sp. nov. beneath the semitransparent abfrontal membrane. Note the paired kenozooidal rootlets and their branches at lower left; these anchor the colony to sediment grains in the soft-sediment habitat. The blue colour of the colony is optical, not staining. B. Optical photograph of the proximal end of a small colony of Onchoporoides moseleyi showing the ancestrular zooid (a) in abfrontal view, with calcified interiors (*) of lateral kenozooids that converge proximally. Scale bars: $A=3 \mathrm{~mm} ; \mathrm{B}=100 \mu \mathrm{m}$. 
Pencil drawings were scanned, digitally inked and arranged as plates using the methods described in Coleman $(2003,2009)$.

The body lengths of amphipod specimens examined were measured by tracing the mid-trunk length from the tip of the rostrum to the end of the telson. For scanning electron microscope (SEM) imaging the specimens and appendages were dehydrated through a graduated ethanol series, acetone dried, mounted on stubs, coated with gold-palladium and investigated via a SEM LEO1525. SEM imaging of the bryozoan host skeleton was carried out using a Hitachi TM3000 Tabletop Microscope.

All material is held in the Marine Invertebrate Collection, NIWA, Wellington.

\section{Results}

Suborder Senticaudata Lowry \& Myers, 2013

Infraorder Corophiida Leach, 1814

Parvorder Corophiidira Lowry \& Myers, 2013

Superfamily Chevalioidea Myers \& Lowry, 2003

Family Chevaliidae Myers \& Lowry, 2003

Genus Bryoconversor gen. nov. urn:1sid:zoobank.org:act:761AFF11-1BB8-4DFD-9126-E15D7C0B8ECB

\section{Type species}

Bryoconversor tutus sp. nov., by monotypy

\section{Etymology}

From prefix bryo- (abbreviation of bryozoan) and Latin conversor, to dwell with.

\section{Diagnosis}

Head lateral cephalic lobes weakly produced forward, subtriangular; anteroventral excavation weak. Eye present. Labrum lacking epistome. Antenna 1 \& 2 subequal in length. Gnathopod 2 larger than gnathopod 1, subchelate; Pereopod 5-7 coxae very shallow. Epimera rounded; Urosome segments 1 and 2 coalesced. Uropods 1-2 biramous, inner ramus longer than peduncle, weakly curved with deep longitudinal ridges and completely lacking setae. Uropod 2 posterior margin with a strongly developed flange with a pitted edge. No sexual dimorphism.

\section{Remarks}

The new genus is very close to Chevalia Walker, 1904, which also lacks sexual dimorphism, but it differs from the latter in the presence, on the posterior margin of the uropod 2 peduncle, of a greatly expanded flange with a pitted edge (whose function is unknown). In Chevalia, the uropod 2 peduncle is unexpanded. In addition, the uropod 1 inner ramus inner margin is smooth in Bryoconversor, but with a row of large serrate spines in Chevalia. It also differs by the deep longitudinal ridges on uropod 1 and 2 inner ramus that are clearly visible under the light microscope in Bryoconversor. These ridges cannot be seen in Chevalia under the light microscope, although confirmation of their absence with SEM would be advisable. 


\section{Bryoconversor tutus sp. nov. urn:1sid:zoobank.org:act:93156279-10B8-4435-A6E0-FF53BFD5F252}

Figs 3-8

\section{Diagnosis}

As for genus.

\section{Etymology}

Latin: 'tutus' = safe.

\section{Material examined}

\section{Holotype}

NEW ZEALAND: NIWA 88918, ovigerous,$+ 1.72 \mathrm{~mm}$ long, station G675, 19 Jan. 1970, 45.4500 S, $171.4000^{\circ} \mathrm{E}, 792 \mathrm{~m}$.

\section{Paratypes}

NEW ZEALAND: Same collection data as for holotype. NIWA 52919, juvenile ô, $0.64 \mathrm{~mm}$ long; NIWA 89534, 4 juveniles, about $0.4 \mathrm{~mm}$ long.

\section{Additional material}

NEW ZEALAND: Several dry specimens. NIWA 89536, st. G705, 23 Jan. 1970, 46.0667 ${ }^{\circ}$ S, $172.4750^{\circ}$ E, 1500 m; NIWA 89533, st. TAN1208/58, 24 Jun. 2012, $42.8107^{\circ} \mathrm{S}, 179.8265^{\circ} \mathrm{E}, 1005 \mathrm{~m}$; NIWA 89535, st. TAN0705/155, 16 Apr. 2007, $42.9989^{\circ} \mathrm{S}, 176.3483^{\circ} \mathrm{W}, 648 \mathrm{~m}$; NIWA 89538, st. C620, 2 May $1961,43.6667^{\circ} \mathrm{S}, 174.7833^{\circ} \mathrm{W}, 752 \mathrm{~m}$; NIWA 89537, st. E827, 24 Oct. 1967, 46.5917 $\mathrm{S}$, $166.7417^{\circ} \mathrm{E}, 530 \mathrm{~m}$.

\section{Description}

Female (holotype, $1.72 \mathrm{~mm}$ long)

HEAD. Lateral cephalic lobes weakly produced forward, subtriangular, anteroventral excavation weak. Eye present. Antenna $1 \& 2$ subequal in length, about half body length. Antenna 1 slender, posterior margin with long slender setae; peduncular articles in the ratios 3:4:3; flagellum less than half length of peduncle, with 7 articles, accessory flagellum with one long and one tiny article. Antenna 2 peduncular articles 4 and 5 subequal; flagellum shorter than peduncle, with 6 articles. Labrum lacking epistome. Mandible molar triturative; palp three-articulate; article 1 short; article 3 a little longer than article 2, elongate sub-ovoid with dense distal setae and a few more sparsely on the posterior distal margin. Labium with subacute mandibular projections. Maxilla 1 inner plate with marginal setae; palp biarticulate with 5 distal robust setae. Maxilla 2 inner plate with oblique setal row. Maxilliped palp much longer than outer plate; dactylus rounded, short, lacking nail.

PEREON. Gnathopod 1 coxa weakly produced forward, sub-acute; basis slender, anterior margin weakly concave; carpus slender, longer than propodus; propodus slender, palm oblique, evenly continuous with posterior margin; dactylus slender, two thirds length of propodus. Gnathopod 2 larger than gnathopod 1; coxa subquadrangular, equal in depth with coxa 1; basis stout, a little over twice as long as broad, anterior margin concave; carpus short, stout, as broad as long; massive propodus nearly twice length of carpus, palm with three processes, a triangular distal spine and two rounded mid-palmar humps; dactylus a little shorter than palm. Pereopods 3-4 slender; coxae subtriangular, about half depth of coxae1-2; dactylus short, about one third length of propodus. Pereopod 5-7 coxae very shallow; carpus small, lunate; merus large and broad; dactylus with accessory spine on anterior margin. Pereopod 7 basis of posterodistal margin with strong projection. 


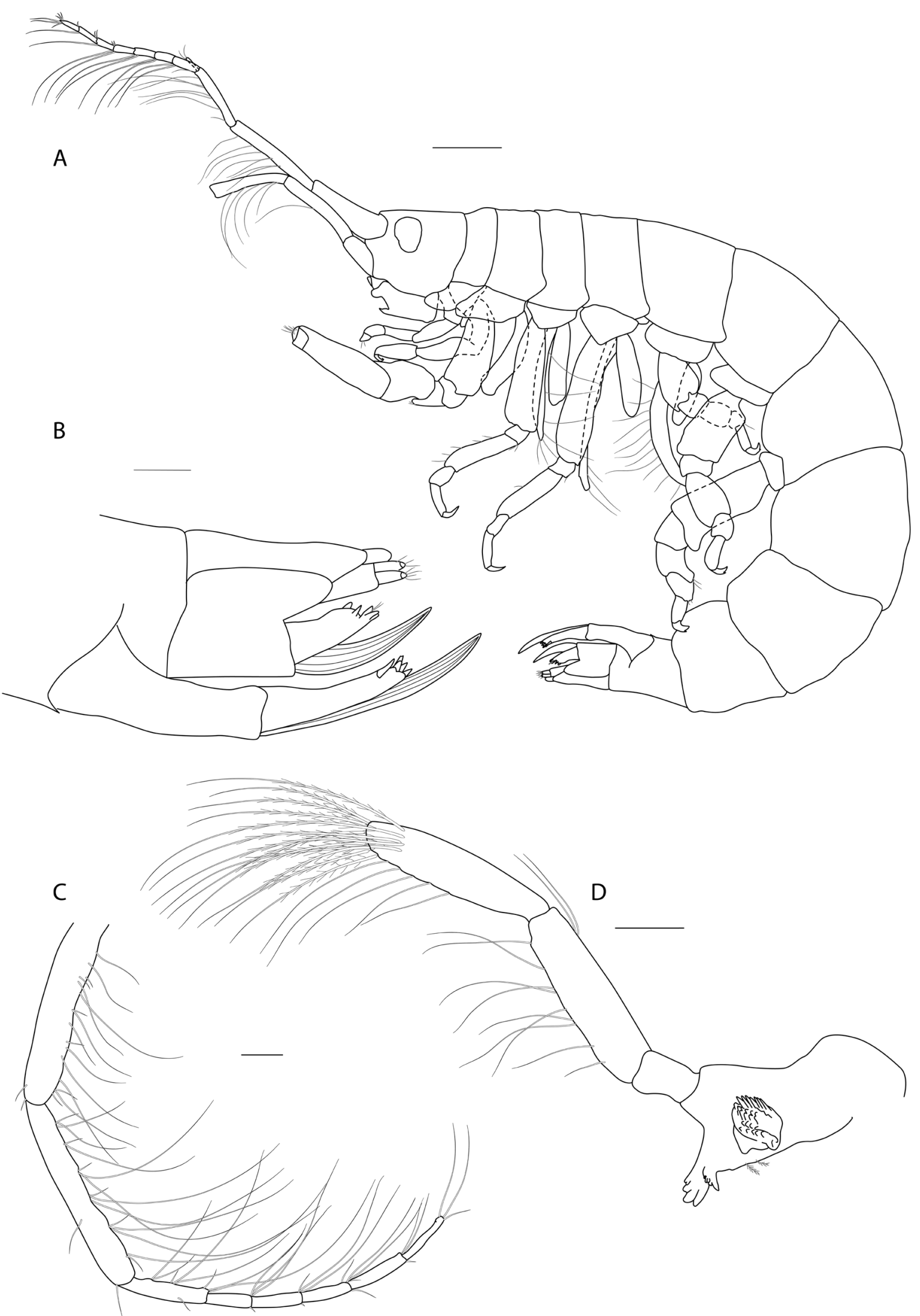

Fig. 3. Bryoconversor tutus gen. et sp. nov., holotype, ㅇ, NIWA 88918, $1.72 \mathrm{~mm}$ long. A. Habitus. B. Urosome. C. Antenna 2. D. Mandible. Scale bars $=100 \mu \mathrm{m}$. 


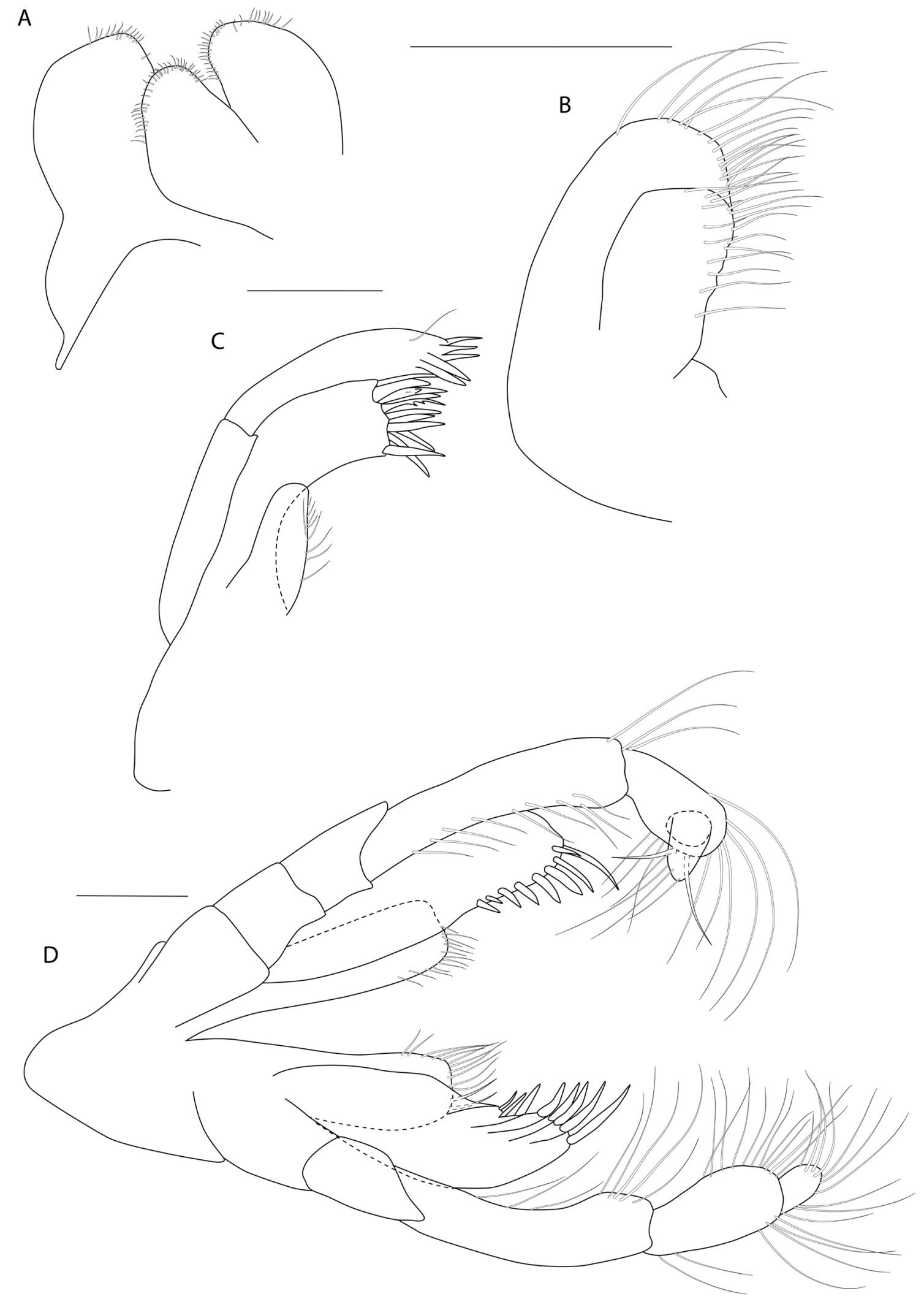

Fig. 4. Bryoconversor tutus gen. et sp. nov., holotype,, , NIWA 88918, 1.72 mm long. A. Hypopharynx. B. Maxilla 2. C. Maxilla 1. D. Maxilliped. Scale bars $=100 \mu \mathrm{m}$. 


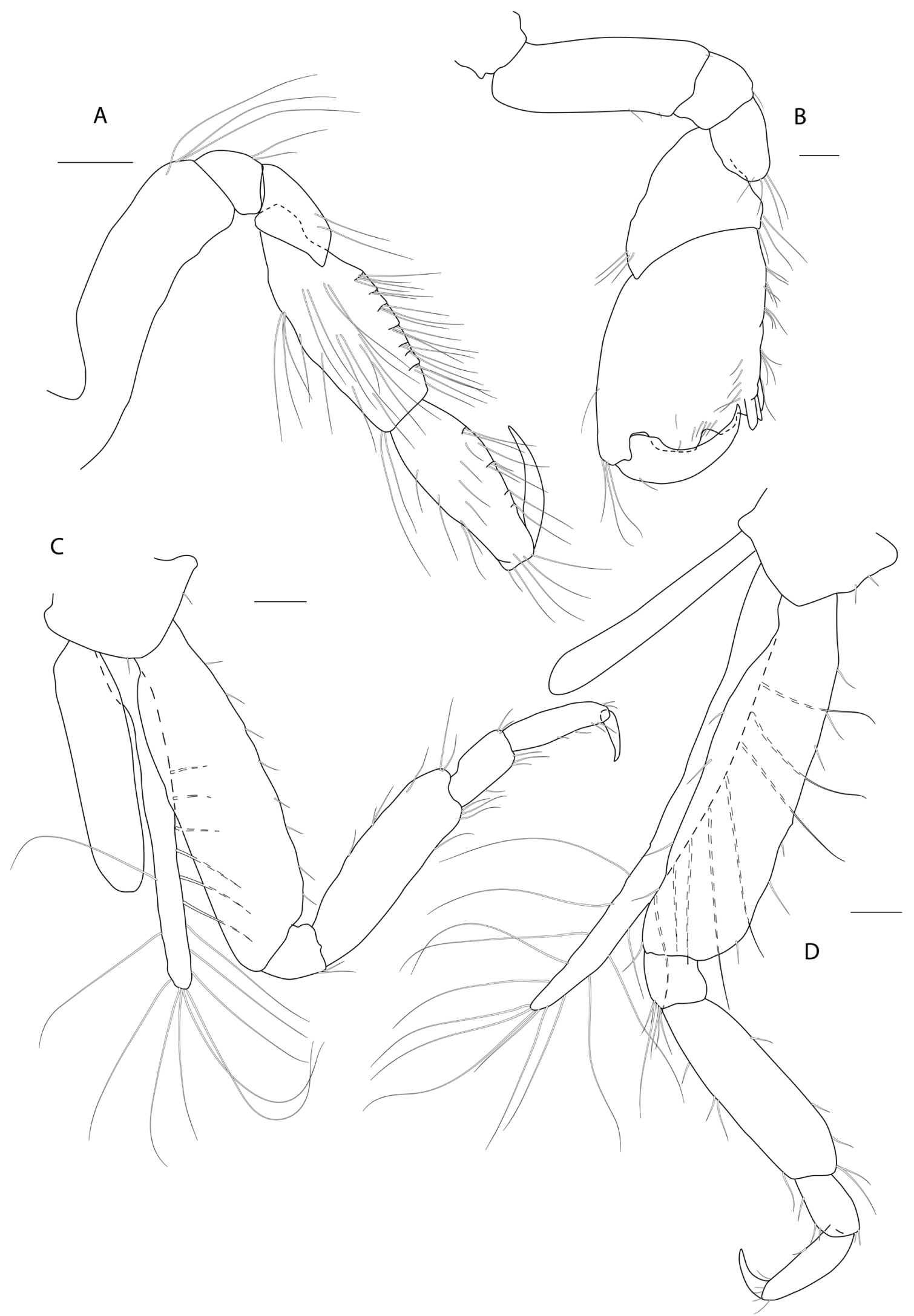

Fig. 5. Bryoconversor tutus gen. et sp. nov., holotype, $q$, NIWA 88918, $1.72 \mathrm{~mm}$ long. A. Gnathopod 1. B. Gnathopod 2. C. Pereopod 3. D. Pereopod 4. Scale bars $=100 \mu \mathrm{m}$. 

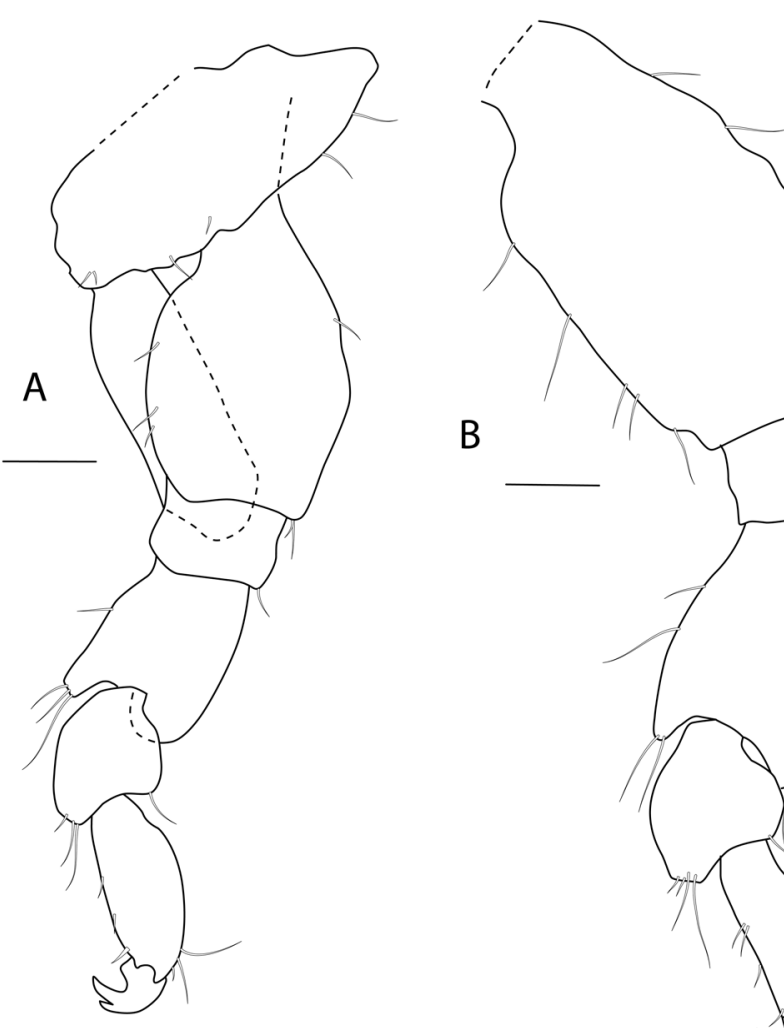

B
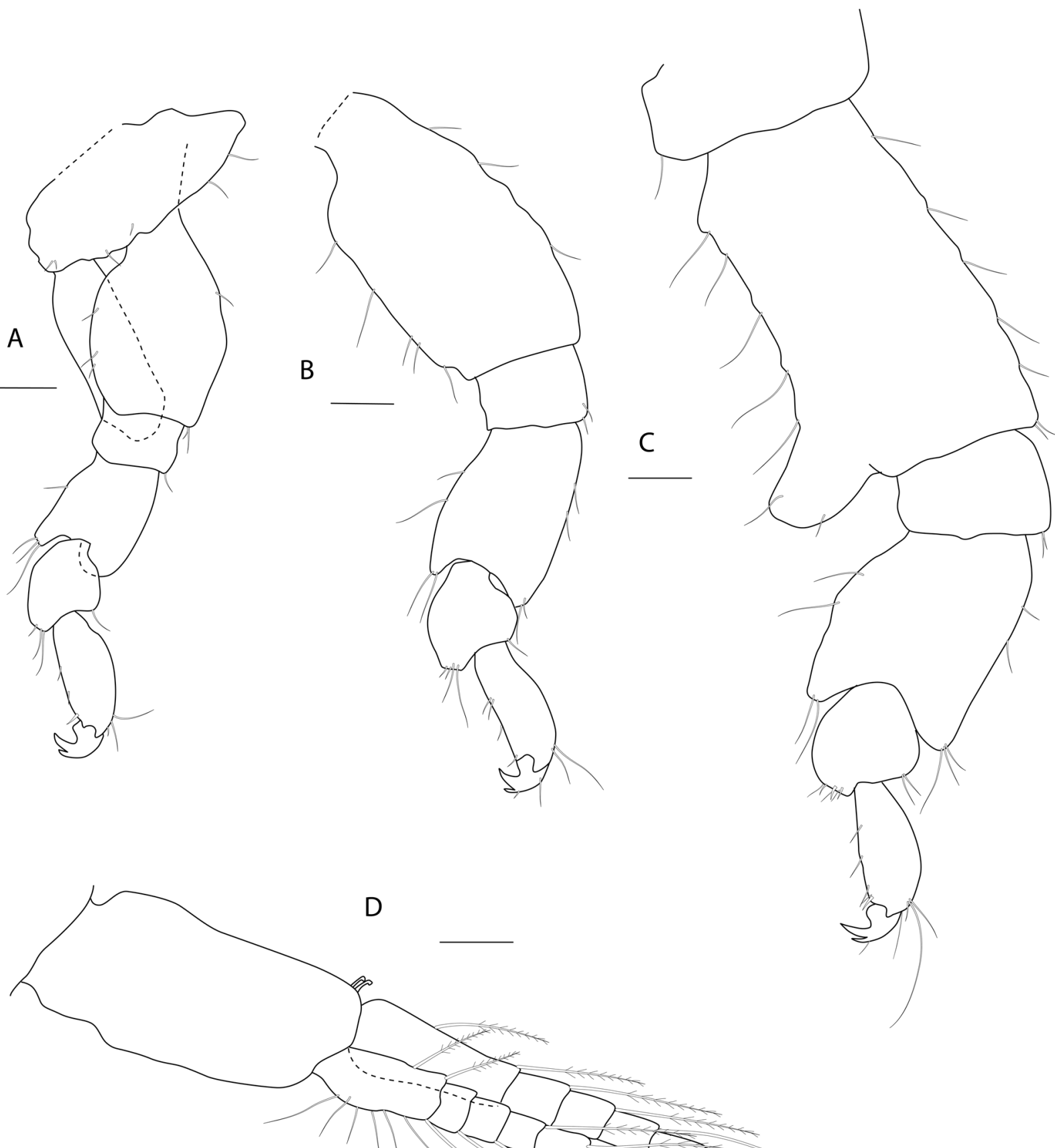

$\mathrm{D}$
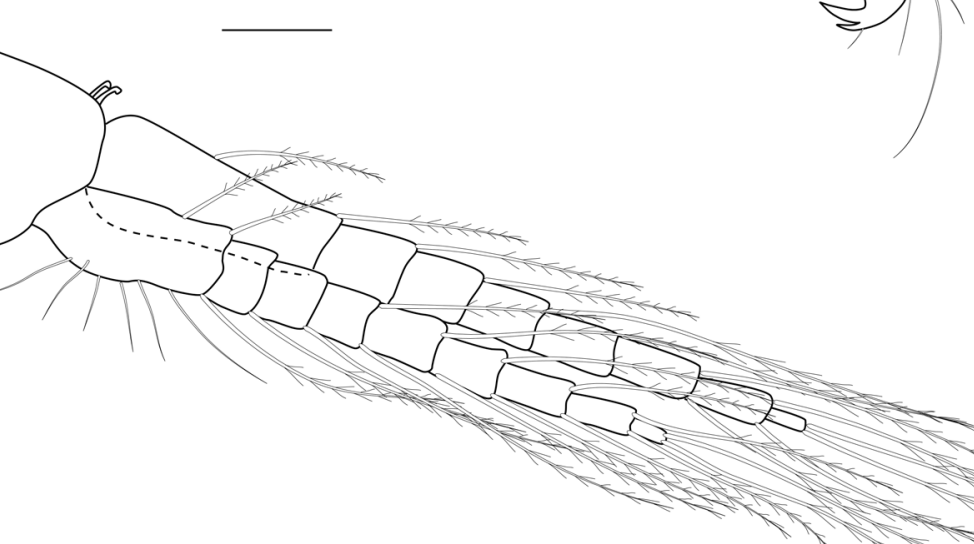

Fig. 6. Bryoconversor tutus gen. et sp. nov., holotype,, , NIWA 88918, $1.72 \mathrm{~mm}$ long. A. Pereopod 5. B. Pereopod 6. C. Pereopod 7. D. Pleopod 1. Scale bars $=100 \mu \mathrm{m}$. 
Pleon. Epimera 1-3 rounded. Urosome segments 1 and 2 coalesced. Uropod 1 biramous, inner ramus longer than peduncle, weakly curved with deep longitudinal ridges and completely lacking setae; outer ramus a little shorter than peduncle with distal robust setae and one sub-distal seta. Uropod 2 posterior margin with a strongly developed flange with a pitted edge; inner ramus longer than peduncle, weakly curved with deep longitudinal ridges and completely lacking setae; outer ramus a little shorter than peduncle, with distal robust setae. Uropod 3 peduncle short, rami subequal in length with peduncle, with terminal setae. Telson dorsoventrally thickened with one long dorsal seta on each side; subdistal margin with a small group of flat-topped projections visible under SEM.
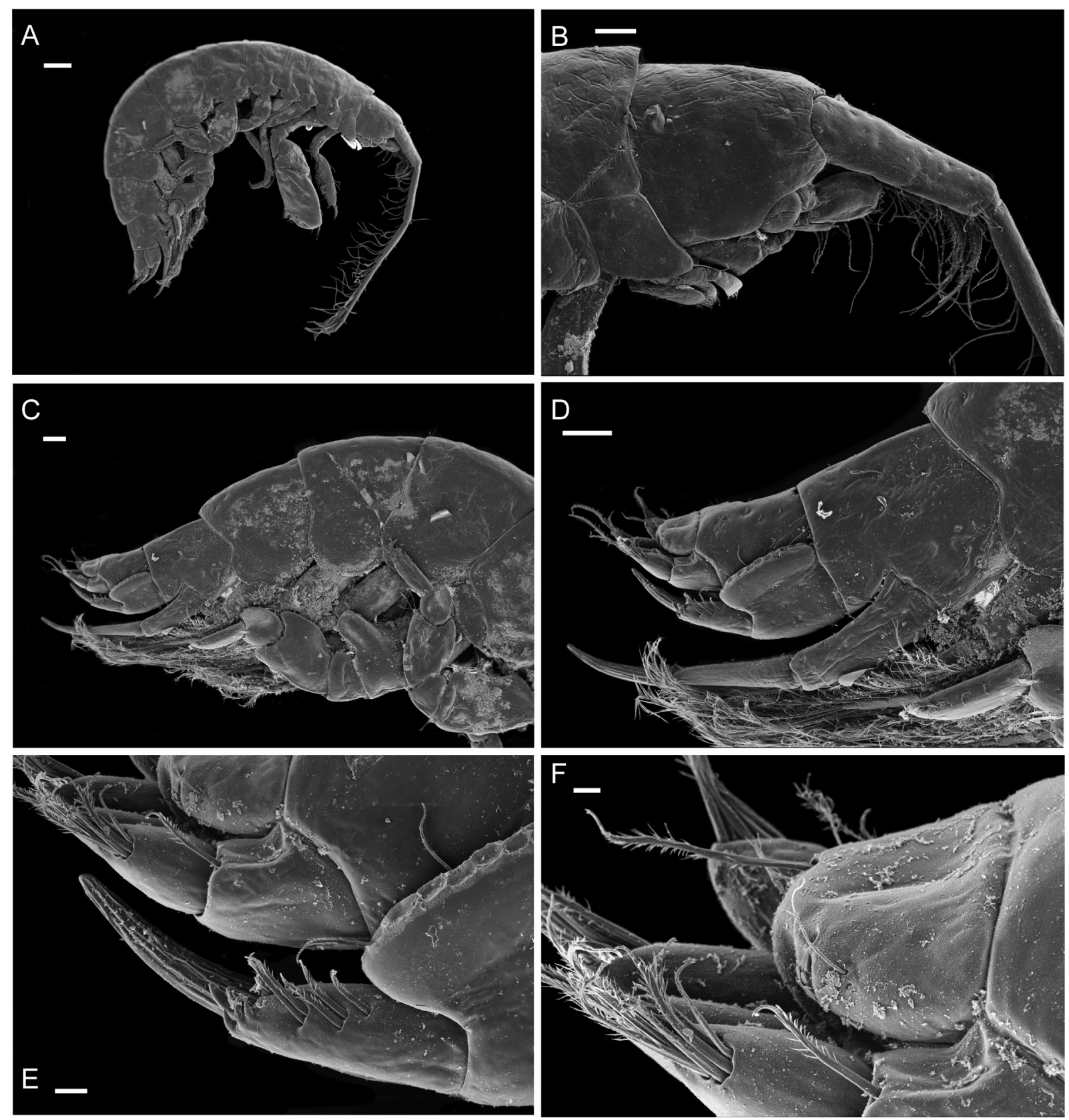

Fig. 7. Bryoconversor tutus gen. et sp. nov., paratype, ô, NIWA 52919, $0.64 \mathrm{~mm}$ long. A. Habitus. B. Head. C. Epimeron. D. Urosome. E. Uropod 2 and uropod 1. F. Telson. Scale bars: A = $300 \mu \mathrm{m}$; B-D = $100 \mu \mathrm{m} ; \mathrm{E}=20 \mu \mathrm{m} ; \mathrm{F}=10 \mu \mathrm{m}$. 


\section{Male}

(Sexually dimorphic characters.) Not different from female, except for much smaller body size.

\section{The bryozoan host}

Onchoporoides Ortmann, 1890 is a nominally monotypic genus of Calwelliidae (Cheilostomata) that is known only from the southwestern Pacific. The sole included species, O. moseleyi, was first collected by the R.V. Challenger from a depth of $951 \mathrm{~m}$ on the Kermadec Ridge north of Macauley Island. Additional
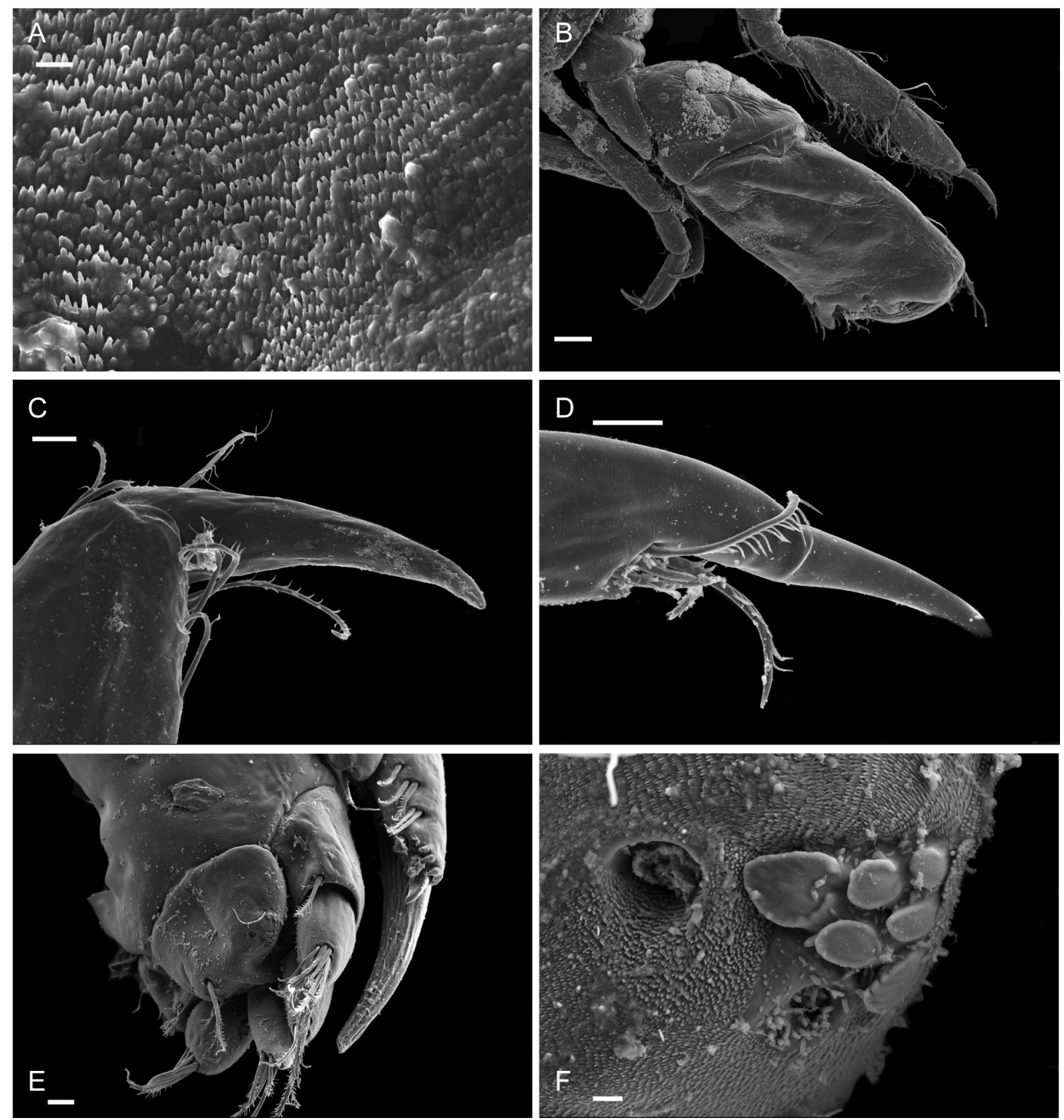

Fig. 8. Bryoconversor tutus gen. et sp. nov., paratype, ô, NIWA 52919, $0.64 \mathrm{~mm}$ long. A. Detail of serrated surface on telson. B. Gnathopod 1 and larger gnathopod 2. C. Dactylus gnathopod 1. D. Dactylus gnathopod 1. E. Dorsal view telson, uropod 3 and uropod 2. F. Flat-topped projections on telson. Scale bars: $\mathrm{A}=1 \mu \mathrm{m} ; \mathrm{B}=100 \mu \mathrm{m} ; \mathrm{C}-\mathrm{D}=10 \mu \mathrm{m} ; \mathrm{E}=20 \mu \mathrm{m} ; \mathrm{F}=2 \mu \mathrm{m}$. 

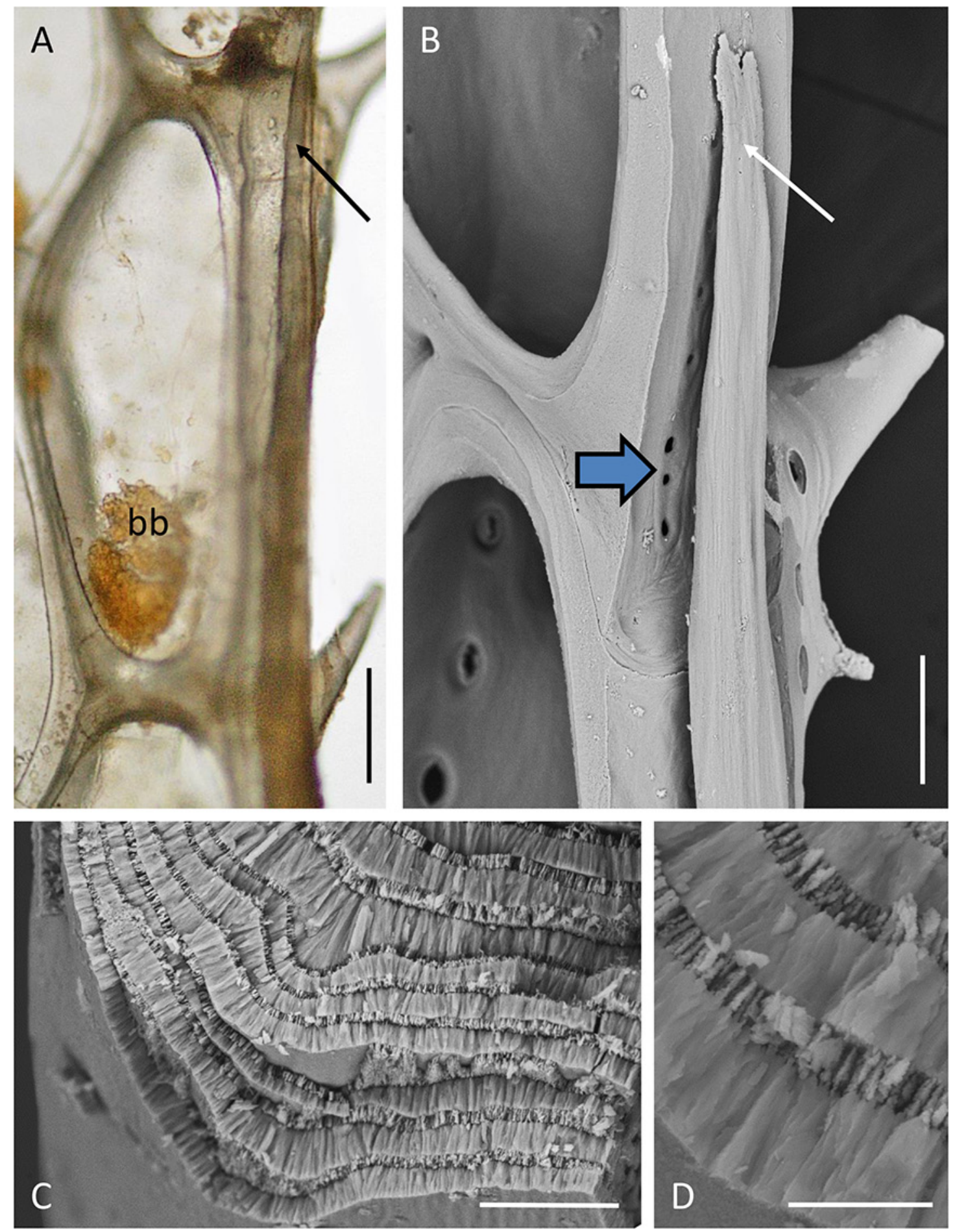

Fig. 9. A. Optical view of the abfrontal side of a distal marginal autozooid (polypide reduced to a residual brown body, bb) adjacent to a lateral kenozooid in which there is a distally tapered (i.e., apically developing) intracoelomic calcareous rod (arrow). B. SEM of a similar view to A but of skeletal elements only, showing the distal tip of the calcareous rod (white arrow) and the communication pores (blue arrowhead) that allow nutrient connectivity between the feeding autozooid and non-feeding kenozooid in which the coelomic cavity comes to be filled by the calcareous rod. C. Fractured transverse section of a calcareous rod showing alternating thick and thin wall-perpendicular prismatic fabric. D. Part of C magnified. Scale bars: A $=200 \mu \mathrm{m} ; \mathrm{B}=100 \mu \mathrm{m} ; \mathrm{C}=25 \mu \mathrm{m} ; \mathrm{D}=5 \mu \mathrm{m}$. 
specimens were subsequently taken by the then New Zealand Oceanographic Institute (now NIWA) from $526 \mathrm{~m}$ in the Solander Trough, at the western approaches to Foveaux Strait, and from $2677 \mathrm{~m}$ in the Hikurangi Trough east of Cook Strait (Gordon 1989). This paper adds additional records, within this depth range, mostly from stations east of South Island. Gordon \& d'Hondt (1997) also reported the species from the Loyalty Basin.

Onchoporoides moseleyi forms planar erect colonies up to $52 \mathrm{~mm}$ high. These can branch dichotomously to give an overall flabellate form and the whole colony is anchored in soft substrata by root-like rhizoids (non-feeding zooidal polymorphs). Like the zooids in the colony, each rhizoid has a calcified body wall. A tubular kenozooid (also a non-feeding bryozoan polymorph) runs down the lateral margin of the colony on each side, converging proximally to form a short stem that divides proximally into numerous individual rhizoids (Fig. 2A) with small lateral processes. The founding individual of a colony (ancestrula) is unusually long $(2 \mathrm{~mm}$ ) for bryozoans. It tapers proximally into two rhizoid-like processes that anchor it. The colony grows by distal budding of new zooids from the ancestrula and its daughter zooids.

The zooids of $O$. moseleyi open only on one face, with resident amphipods dwelling on the abfrontal side (Fig. 2A) where they apparently do not interfere with the life processes of the bryozoan. Enclosing the amphipods is a semitransparent membrane that is attached to each outer margin, conforming to the shape of the colony. The space enclosed by the membrane is interpreted to be a colony-wide extrazooidal basal coelom and its membrane an ectocyst (cuticularized epithelium). Gordon (1989) noted the apparent universality of the membrane in the colonies he examined, with the possible exception of very small colonies in which he failed to detect a membrane, perhaps because of its transparency. Busk (1884) described the species on the basis of a single specimen $19 \mathrm{~mm}$ high and did not mention an abfrontal membrane or any association with amphipods.

Examination of growing margins of $O$. moseleyi by light microscopy and SEM indicates that the basal coelom and ectocyst are laterally contiguous with the continuous marginal kenozooid ('extrazooidal marginal coelom' of Cook \& Chimonides 1981) on each side of the branch. The basal coelom probably originates from the vicinity of the ancestrula (Fig. 2B) when it buds the first daughter zooids distally, each with a lateral kenozooid and the presumed inception of the basal coelom and ectocyst between them. Later in colony ontogeny, the first settler amphipod (possibly a hermaphrodite or a female with an attached male companion) is inferred to cut an entrance slit in the ectocyst, presumably using its gnathopods, in order to insert itself beneath, but not so destructively as to wholly interfere with the integrity of the basal coelom (though there must be some leakage or loss of coelomic fluid). One dried colony shows a longitudinal slit in the ectocyst where it would otherwise attach to the lateral kenozooid, with the tips of amphipod appendages protruding, but it is not clear if the tear is a consequence of drying or made by the amphipod. Self-repair is well documented in bryozoans (e.g., Ryland 1970) and a slit made by an amphipod to enter the basal coelom would quickly repair. We believe it much more likely that resident amphipods would remain within the basal coelom, surviving on nutrient transfer from the bryozoan, rather than constantly exiting and returning or sustaining an opening in the basal membrane for feeding. Continual loss of coelomic fluid would compromise the integrity of the extrazooidal basal coelom, whereas it is evident from the continued differentiation of the distal branch tips of the colony by intussusception that this must not be the case.

There are no communication pores in autozooidal basal walls (which are, however, uncalcified, allowing diffusion across the thinly cuticularised epithelium). There are such pores in the lateral walls, including those abutting the marginal kenozooidal tube as it differentiates on each side of a branch. At their distal tips, the marginal kenozooids are hollow and filled with coelomic fluid. Proximal to each tip the tapered distal end of a developing intracoelomic calcified rod is visible (Fig. 9A-B). This rod occupies the remainder of the kenozooid, fully occupying the coelomic cavity. A transverse fracture of the rod shows 
it to have a wall-perpendicular prismatic fabric (cf. Weedon \& Taylor 2000) made up of thick and thin layers (Fig. 9C-D).

\section{Discussion}

Commensalism describes a relationship between two living organisms in which one benefits and the other is not significantly harmed or helped and that appears to be the case here - the bryozoan provides shelter or housing for the amphipod, hence the association is a case of inquilinism.

The existence of the extrazooidal basal coelom that accommodates the amphipod residents is puzzling, as it has not been reported in any other calwelliid species. The precise conformity of its enclosing membrane to the shape of the bryozoan, from the proximal-most zooids to the branch tips, supports the inference that it is produced by the bryozoan. All colonies in the collection have a basal coelom and ectocyst. In addition, it appears improbable that it could have been produced by the amphipod, as there is no known mechanism whereby it could secrete (or induce) such a membrane and secure it precisely to the lateral margins of the bryozoan. Extrazooidal basal coeloms have been found in several cheilostome families. Examples include species of Cupuladriidae (Håkansson 1973; Tavener-Smith 1973), Euthyrisellidae and Didymosellidae (Cook \& Chimonides 1981), Selenariidae (Chimonides \& Cook 1981) and Urceoliporidae (Gordon 1988). In their discussion, Cook \& Chimonides (1981, p. 81) also briefly mention the presence of "an extensive" extrazooidal basal coelom in Petraliidae and in their text (p. 62) they note that "extrazooidal marginal coelomic systems ... resemble those formed by lateral kenozooids in ... Onchoporella buskii" (see Florence et al. 2007: fig. 201). However, they did not mention an extrazooidal basal coelom in this calwelliid species, in which it thus seems to be absent.

The kenozooidal intracoelomic calcareous rod has not been reported before and the alternation of dense layers with thinner layers (Fig. 9C-D) is likewise novel. The thin layers appear as though they may have a higher organic content. The layered nature of the rod would render it less prone to fracture from stresses on the colony, especially if semi-organic layers allowed for minute internal "slippage" of layer against layer. Preserved colonies can bend slightly which implies that this is possible in nature.

Although the bryozoan host does not appear to benefit from or be harmed by the association, the question arises concerning the selection pressure that resulted in the unique internal calcification of the marginal kenozooids. As indicated above, other members of the family Calwelliidae, especially Onchoporella buskii and species of Ichthyaria that also form planar fronds, either lack marginal kenozooids (four of the five species of Ichthyaria) or the kind of calcification that results in a vertical intracoelomic rod. (Ichthyaria simplex Gordon \& d'Hondt, 1997 from New Caledonia has marginal kenozooids and lacks a basal uncalcified window in each zooid and should be transferred to Onchoporoides. It is not known if the marginal kenozooids have an intracoelomic rod.) We have no evidence that the presence of the amphipod induces the formation of either the extrabasal coelom or the kenozooidal intracoelomic rod. Both would impart strengthening of the bryozoan colony, preventing excessive intracolony flexing or bending although, arguably, given the fact that the colony is rooted in soft sediment, bending of the entire colony from the base is likely to be possible. An extrazooidal basal coelom would also strengthen the colony and reduce intracolony bending and flexing, especially in combination with intracoelomic calcification of the marginal kenozooids.

Our interim conclusions and hypotheses are: 1) the extrazooidal basal coelom is produced by the bryozoan, not induced by the amphipod; 2) a hermaphrodite or a female, accompanied by a smaller, attached male gains entrance to the extrabasal coelomic cavity by making a slit that subsequently repairs itself; 3) the amphipods live and reproduce within the coelom, relying on nutrients provided by the bryozoan; 4) when the bryozoan colony is damaged or dies the amphipods exit the coelom and colonize 
other available bryozoans in the same habitat. The relationship appears to be one-sided, benefiting the amphipod by providing nutrients and shelter (protection from predation). Potentially, an entire bryozoan colony and its resident amphipods could be eaten by a relatively large predator (see Lidgard 2008 for examples of predation on bryozoans) but many bryozoans have biochemical defenses that deter predation. The bryozoan host would seem not to benefit from the association, unless the amphipod secretes or excretes organic molecules that the host can uptake. It has been established, for example, that bryozoans are able to uptake dissolved organic carbon (examples in Gordon et al. 1987).

\section{Acknowledgements}

Specimens studied here were collected under numerous research projects funded by the New Zealand Ministry for Primary Industries; the historic samples were collected by the former New Zealand Oceanographic Institute (now the National Institute of Water \& Atmospheric Research, NIWA).

We thank the NIWA Marine Invertebrate collection team for registration and curation of the specimens, Erika MacKay (NIWA) for digitally inking several pencil drawings and Peter Gerring (NIWA) for creating the map. Renate Walter (Zoological Museum Hamburg) kindly assisted with the scanning electron microscope. Two anonymous reviewers vastly improved an earlier version of this paper. This work has been supported by NIWA through Coasts and Oceans Research Programme 2 (Marine Biological Resources) taxonomy project COBR1402.

\section{References}

Boeck A. 1872. De Skandinaviske og Arktiske Amphipoder. Christiana [Oslo], A.W. Brogger. http:// dx.doi.org/10.5962/bhl.title.9921

Busk G. 1884. Report on the Polyzoa collected by H.M.S. Challenger during the years 1873-76. Part I - The Cheilostomata. Report on the Scientific Results of the Voyage of H.M.S. Challenger, Zoology 10(30): xxiv, 1-216.

Chimonides P.J. \& Cook P.L. 1981. Observations on living colonies of Selenaria (Bryozoa, Cheilostomata). Cahiers de Biologie Marine 22: 207-219.

Coleman C.O. 2003. "Digital inking": How to make perfect line drawings on computers. Organisms, Diversity and Evolution, Electronic Supplement 14: 1-14. http://senckenberg.de/odes/03-14.htm, accessed May 2009.

Coleman C.O. 2009. Drawing setae the digital way. Zoosystematics and Evolution 852: 305-310. http:// dx.doi.org/10.1002/zoos.200900008

Cook P.L. 1985. Bryozoa from Ghana: a preliminary survey. Annales du Musée Royal de l'Afrique Central 238: 1-315.

Cook P.L. \& Chimonides P.J. 1981. Morphology and systematics of some interior-walled cheilostome Bryozoa. Bulletin of the British Museum (Natural History). Zoology 41: 53-89.

Eggleston D. 1971. Synchronization between moulting in Calocaris macandreae (Decapoda) and reproduction in its epibiont Triticella korenii (Polyzoa Ectoprocta). Journal of the Marine Biological Association of the United Kingdom 51: 404-410. http://dx.doi.org/10.1017/S0025315400031878

Ehlers E. 1876. Hyphoporella expansa. Ein Beitrag zur Kenntnis der minirenden Bryozoen. Abhandlungen der Königlichen Gesellschaft der Wissenschaften zu Göttingen, Physikalische Classe 21: 1-156.

Florence W.K., Hayward P.J. \& Gibbons M.J. 2007. Taxonomy of shallow-water Bryozoa from the west coast of South Africa. African Natural History 3: 1-58. 
Gordon D.P. 1988. The bryozoan families Sclerodomidae, Bifaxariidae, and Urceoliporidae and a novel type of frontal wall. New Zealand Journal of Zoology 15: 249-290. http://dx.doi.org/10.1080/0301422 $\underline{3.1988 .10422619}$

Gordon D.P. 1989. The marine fauna of New Zealand: Bryozoa: Gymnolaemata (Cheilostomida Ascophorina) from the western South Island continental shelf and slope. New Zealand Oceanographic Institute Memoir 97: 1-158.

Gordon D.P. \& d'Hondt J.-L. 1997. Bryozoa: Lepraliomorpha and other Ascophorina, mainly from New Caledonian waters. In: Crosnier A. (ed.) Résultats des Campagnes Musorstom, vol. 18. Mémoires du Muséum National d'Histoire Naturelle 176: 9-124.

Gordon D.P. \& Wear R.G. 1999. A new ctenostome bryozoan ectosymbiotic with terminal-moult paddle crabs (Portunidae) in New Zealand. New Zealand Journal of Marine and Freshwater Research 26: 373 380. http://dx.doi.org/10.1080/03014223.1999.9518200

Gordon D.P., Clark A.G. \& Harper J.F. 1987. Bryozoa. In: Pandian T.J. \& Vernberg F.J. (eds) Animal Energetics, vol. 2. Bivalvia through Reptilia: 173-199. San Diego, Academic Press. http://dx.doi. org/10.1016/B978-0-12-544792-8.50007-3

Håkansson E. 1973. Mode of growth of the Cupuladriidae (Bryozoa, Cheilostomata). In: Larwood G.P. (ed.) Living and Fossil Bryozoa: Recent Advances in Research: 287-298. London \& New York, Academic Press.

Harmelin J.-G., Boury-Esnault N. \& Vacelet J. 1994. A bryozoan-sponge symbiosis: the association between Smittina cervicornis and Halisarca cf. dujardini in the Mediterranean. In: Hayward P.J., Ryland J.S. \& Taylor P.D. (eds) Biology and Palaeobiology of Bryozoans: 69-74. Fredensborg, Olsen \& Olsen.

Hayward P.J. 1985. Ctenostome bryozoans. Keys and notes for the identification of the species. Synopses of the British Fauna, New Series 33: 1-169.

d'Hondt J.-L. 1983. Tabular keys for identification of the Recent ctenostomatous Bryozoa. Mémoires de l'Institut Océanographique, Monaco 14: 1-134.

Leach W.E. 1814. Crustaceology. Appendix. The Edinburgh Encyclopaedia 7: 429-434.

Lidgard S. 2008. Predation on marine bryozoan colonies: taxa, traits and trophic groups. Marine Ecology Progress Series 359: 117-131. http://dx.doi.org/10.3354/meps07322

Lörz A.N. \& De Broyer C. 2004. Description and ecology of a spongicolous lysianassoid amphipod (Crustacea) from Antarctica. Journal of Natural History 38: 889-899. http://dx.doi. org $/ 10.1080 / 0022293021000046513$

Lowry J.K \& Myers A.A. 2013. A phylogeny and classification of the Senticaudata subord. nov. (Crustacea: Amphipoda). Zootaxa 3610: 1-80. http://dx.doi.org/10.11646/zootaxa.3610.1.1

McKinney F.K., Broadhead T.W. \& Gibson M.A. 1990. Coral-bryozoan mutualism: structural innovation and greater resource exploitation. Science 248: 466-468. http://dx.doi.org/10.1126/science.248.4954.466

Myers A.A. \& Lowry J.K. 2003. A phylogeny and a new classification of the Corophiidea Leach, 1814 (Amphipoda). Journal of Crustacean Biology 23: 443-485. http://dx.doi.org/10.1163/2002197599990353

Myers A.A. 1974. A new species of commensal amphipod from East Africa. Crustaceana 26: 33-36. http://dx.doi.org/10.1163/156854074X00046

Ortmann A. 1890. Die japanische Bryozoenfauna (Bericht über die von Herrn Dr. L. Döderlein im Jahre 1880-81 gemachten Sammlungen). Archiv für Naturgeschichte 54: 1-74, 4 pls. 
Puce S., Bavestrello G., Di Camillo G. \& Boero F. 2007. Symbiotic relationships between hydroids and bryozoans. Symbiosis 44: 137-143.

Ryland J.S. 1970. Bryozoans. London, Hutchinson University Library.

Souza-Filho J.F., Souza A.M.T. \& Valerio-Berardo M.T. 2010. Six new species of the genus Chevalia Walker, 1904 (Amphipoda, Corophiidea, Chevaliidae) from Brazilian waters, with a key to world species of the genus. Zootaxa 2713: 25-51.

Tavener-Smith R. 1973. Some aspects of skeletal organization in Bryozoa. In: Larwood G.P. (ed.) Living and Fossil Bryozoa: Recent Advances in Research: 349-359. London \& New York, Academic Press.

Taylor P.D. 1994. Evolutionary palaeoecology of symbioses between bryozoans and hermit crabs. Historical Biology 9: 157-205. http://dx.doi.org/10.1080/10292389409380497

Vader W. 1972. Associations between amphipods and molluscs. A review of published records. Sarsia 48: 13-18.

Vader W. 1984. Associations between amphipods (Crustacea: Amphipoda) and sea anemones (Anthozoa; Actiniaria). Memoirs of the Australian Museum 18: 141-153. http://dx.doi.org/10.3853 j.j.0067-1967.18.1984.380

Vader W. \& Krapp T. 2005. Crab-associated amphipods from the Falkland Islands (Crustacea, Peracarida). Journal of Natural History 39: 3075-3099. http://dx.doi.org/10.1080/00222930500218573

Vader W. \& Myers A.A. 1996. Amphipods living in association with hermit crabs in S.E. Australia. 1. Five new Ischyroceridae. Bollettino di Museo Civico di Storia Naturale, Verona 20: 263-292.

Walker A.O. 1904. Report on the Amphipoda collected by Professor Herdman, at Ceylon, in 1902. Report of the Government of Ceylon Pearl Oyster Fishery of the Gulf of Manaar 17: 229-300.

Weedon M.J. \& Taylor P.D. 2000. Skeletal ultrastructure of primitive cheilostome bryozoans. In: Herrera Cubilla A. \& Jackson J.B.C. (eds) Proceedings of the 11th International Bryozoology Association Conference: 400-411. Balboa, Smithsonian Tropical Research Institute.

White K.N. \& Reimer J.D. 2012a. Commensal Leucothoidae (Crustacea, Amphipoda) of the Ryukyu Archipelago, Japan. Part I: ascidian-dwellers. Zookeys 163: 13-55. http://dx.doi.org/10.3897/ zookeys.163.2003

White K.N. \& Reimer J.D. 2012b. Commensal Leucothoidae (Crustacea, Amphipoda) of the Ryukyu Archipelago, Japan. Part II: sponge-dwellers. Zookeys 166: 1-58. http://dx.doi.org/10.3897/ zookeys.166.2313

Manuscript received: 24 October 2013

Manuscript accepted: 1 January 2014

Published on: 29 January 2014

Topic editor: Rudy Jocqué

Desk editor: Danny Eibye-Jacobsen

Printed versions of all papers are also deposited in the libraries of the institutes that are members of the EJT consortium: Muséum National d'Histoire Naturelle, Paris, France; National Botanic Garden of Belgium, Meise, Belgium; Royal Museum for Central Africa, Tervuren, Belgium; National History Museum, London, United Kingdom; Royal Belgian Institute of Natural Sciences, Brussels, Belgium; Natural History Museum of Denmark, Copenhagen, Denmark. 